and in neither case themselves entitled to be called protovertebrates, or else that the protovertebrates referred to were ichthyopsida, that is to say, more simply, allied to the amphibia. I do not object to that litter supposition. I suggested it myself in 1884 (Fournal of Anatomy and Physiology, xviii. p. 356), as perhaps Prof. Parker is aware. But if birds are developed from amphibians or pre-amphibians, and if Prof. Huxley is right, as I believe he is, in supposing that the connection of mammals with amphibians is neither through reptiles nor birds, we come to this: that amphibians or pre-amphibians have furnished the common stem whence reptiles, birds, and mammals have diverged. In that case there is an end of that group, "Sauropsida," which the birds are alleged by Prof. Parker to "culminate."

But, further, amphibians are certainly more closely allied to reptiles than to either birds or mammals. Cuvier's system may therefore be justly reverted to, and the Amphibia or Batrachia be considered as the lowest division of the Reptilia, which I do not for one moment doubt is the true classification.

University, Glasgow, February 8

John Cleland

The West Indian Seal (Monachus tropicalis)

IT will probably be of interest to the zoological portion of your readers to learn of the re-discovery-or the full discoveryof the West Indian seal (Monachus tropicalis). The history of this pinniped is in brief as follows.

It was first noticed by Columbus in his accoun of his second voyage (1494) as having been found in some numbers on the rocky isle of Alta Vela, off the southern shore of Hispaniola, where his sailors killed eight of them for food. Later-in I675 -Dampier found this seal in abundance on the Alacram reefs, about 80 miles north of Yucatan. At that time it was killed there in great numbers for its oil.

The seal then remained unnoticed for over a century and a half having no place whatever in the writings of zoologists unti r843. Then Mr. Richard Hill published an account of it in the "Jamaica Almanac," calling it the Pedroseal, from the Pedro Keys, some 60 miles south of Kingston, Jamaica, where he had found it. A few years later Mr. P. H. Gosse obtained an imperfect skin (without skull) which he sent to the British Museum, where it was described by Dr. Gray in the Proceedings of the Zoological Society of London, I849. Dr. Gray gave it then no name, probably by reason of its imperfect characters. Later-in 1850-(Catalogue of Mammals in the British Museum) he described this same specimen as Phoca tropicalis, and afterwards (Catalogue of Seals and Whales, I866) as Monachus tropicalis. But so imperfect was the specimen on which the description was founded, and the animal itself was so little known, that even its generic relations were in doubt, and its reference to the genus Monachus was considered provisional. From thence on to the present, rumours of the existence of this seal have been not unfrequent, but nothing seemed trustworthy and positive, and no specimens were obtained, if we except a young skin, without bones or skull, which came from Cuba to the National Museum at Washington, in 1884 , without any indication as to locality.

It has long seemed to the writer-as, doubtless, to many others - that the certain presence in our waters of so important a mammal lying perdu in regions which our naturalist collectors are yearly visiting, was the opprobrium of Ainerican zoologists. We made inquiries, and collected notes from many sources, which showed clearly that this seal existed at isolated points -on small islands and keys-not only in the Caribbean and among the Bahamas, but also in the Gulf of Mexico. Last summer, while on a visit to the western shore of the Gulf of Mexico, we were so fortunate as to locate this seal with much certainty. This was upon the Triangles (Los Triangulos), three little keys, hardly above the water-level at high tide, and lying sorne 100 miles north-west off the Campeachy coast, in latitude N. $20^{\circ} 50^{\prime}$, and longitude W. $92^{\circ} 10^{\prime}$. Following this clue, my son, Mr. Henry L. Ward, last December visited the Triangles in company and partnership with Señor F. Ferrari Perez, naturalist of the Mexican Geographical and Exploring Expedition. His hunt was highly successful, and he has during the present month returned with nearly twenty specimens-skeletons and skins of all ages, from a suckling to the fully adult male, 7 feet in length. This ample material has just been carefully studied by Prof J. A. Allen, the well - known zoologist, and author of the
"Monograph of North American Pinnipeds." Prof. "Allen has given a preliminary notice of the specimens in Science, January 14, I887, and promises an elaborate account, with plates, in an early issue of the Bulletin of the American Museum of Natural History, New York.

It is a fact of rather peculiar interest that this, the first large mammal ever discovered in America, should, by the strange mishaps of natural history collecting, be the very last one to become known satisfactorily to science. HENRY A. WARD

Rochester, N.Y., January 30

\section{An Abnormal Hirudo medicinalis}

WHILST dissecting the leech in the class of practical zoology, one of my students directed my attention to an apparent abnormality in the specimen which it fell to his lot to dissect. On careful examination it was found that the vesicula seminalis of the right side had moved forwards into the fifth somite, and there opened into the base of a second and fully-developed penis, which opened to the exterior on the second annulus of the fifth somite. From the vas deferens, however, there passed off to the normal penis a duct which had on it a swelling corresponding in position to the vesicula seminalis, which had been moved forwards. The various parts on the left side, as well as the female organs, were quite normal.

Biological R. J. HARvey Grbson February 14

\section{Instinctive Action}

SOME years ago I was about to drown a terrier pup of about a month old. I held it across the palm of my open hand over a large tub of water. It lay quite still on my hand as I gently lowered it. When within 4 inches of the surface, but not yet touching the water, it deliberately began, and continued as long as I held it there, the paddling motion with its feet peculiar to dogs when swimming, and quite unlike that of walking, although I am perfectly certain this puppy had never seen or touched water before. We know almost all animals swim when first placed in water, but how could this puppy know before it touched the water that this peculiar action would be necessary? Has a similar case been observed by any of your readers?

Birmingham, February 17

D. W. C.

\section{THE RELATIONS BETWEEN GEOLOGY AND THE MINERALOGICAL SCIENCES'}

I.

THE realm of Nature has been recognised from time immemorial as consisting of three kingdoms: dealing with the affairs of these three kingdoms, respectively, there have grown up side by side three departments of natural knowledge-zoology, botany, and mineralogy. But in recent years new and, I cannot help thinking, regrettable relations have sprung up between these sister sciences. Zoology and botany, having developed a method, a classification, and a nomenclature, based on common principles, have been drawn together by bonds so close and firm that many regard them as indissolubly one - the science of biology. Mineralogy, thus isolated, has been driven to seek new and unnatural alliances-with chemistry, with physics, or with the mathematical sciences. For my own part I confess that I regard this threatened "Repeal of the Union" of the natural sciences as alike a misfortune and a mistake.

It is sometimes assumed that the objects dealt with by zoology and botany are so different in their essential characters from those treated of by mineralogy, that the science of "organic" Nature must always follow a different path from that pursued by the science of "inorganic" Nature. The structures commonly known as organic, and the processes usually called vital, are asserted to be so entirely different, alike in their origin and in their essence,

I Address to the Geological Society at the Anniversary Meeting on February 18 , by the President, Prof. John W. Judd, F.R.S. 